\title{
Al Combine with Wishing Tree Hole, Spitting Tree Hole and Shared Time Bank
}

\author{
Shih-Feng Chang, Wei-Zheng Zhang, Wan-Yin Liang, Jia-Yue Qiu, Sui Pan and Ya-Yuan Huang* \\ Nanfang College of Sun Yat-Sen University, Guangzhou, 510970, China
}

\begin{abstract}
Under the thinking of "sharing economy", Wish Magic wants to create a platform called "shared time bank", so that users of the platform can store their free time in the "shared time bank" platform in advance. Then, according to the precise docking of products and services as well as supply and demand, Wish Magic also carries out the "wishing tree hole" platform to effectively interact with users according to the latest news and wish list released by users, and regularly goes to poor areas to carry out relevant poverty alleviation activities, so as to provide education support for local people with educational needs and truly play the role of targeted poverty alleviation. In addition, in today's situation of prevailing pressure, Wish Magic will also create a "spitting tree hole" platform to provide a space for everyone to spit and vent their negative energy, and provide advice for everyone in work, study, love or marriage and other aspects, and help to solve practical problems. The combination of these three platforms enable people to arrange their time reasonably, make effective use of resources, and help people improve their work efficiency and quality of life, so as to create greater economic and social benefits.
\end{abstract}

\section{Introduction}

Based on the different needs of the market, Wish Magic combined with the concept of shared time bank to develop the first two project products, namely wishing tree hole and spitting tree hole.

First of all, according to the precise docking of products and services as well as the supply side and demand side, Wish Magic carries out the "wishing tree hole" activity, effectively interacts with users according to the latest trends and wish list released by users, and regularly goes to poor areas to carry out relevant poverty alleviation activities.

Secondly, with the improvement of people's living standards, idle resources will also increase. Among them, spare time is also a kind of shared resources. Wish Magic matches the right listeners according to the service needs of the complainants, so as to help consumers quickly and accurately find the services they want, and play the role of mutual benefit.

At the same time, as a shared resource adhering to the development concept of "sharing resources with science and technology", through the combination of artificial intelligence and big data, the service platform provides online consultation and practical problem solving + offline activities and lectures, and divides the product service types into four parts: work, study, love and life.

\section{Literature Review}

On March 4, 2020, the Sharing Economy Research Center of the State Information Center issued the "China's Sharing Economy Development Report (2020)", which comprehensively reflects the development situation of China's sharing economy in 2019. From the report, we can see that the sharing economy plays a positive role in stabilizing employment. Under the pressure of the overall employment situation, the employment in the field of sharing economy still maintains a rapid growth. The number of participants in the sharing economy is about 800 million, including 78 million service providers, a year-on-year increase of $4 \%$.

Besides, the role of sharing economy in promoting the structural optimization of service industry and promoting the transformation of consumption mode is also further revealed. In 2019, the share of new forms of sharing economy in taxi and accommodation sectors in the industry will reach $37.1 \%, 12.4 \%$ and $7.3 \%$ respectively, $20.5 \%, 7.8 \%$ and $3.8 \%$ higher than that in 2016 .

In addition, on July 15, 2020, the National Development and Reform Commission and other 13 Ministries and Commissions issued the "opinions on supporting the healthy development of new formats and new models, activating the consumer market and promoting the expansion of employment". The policy also reflects that the sharing economy will play an increasingly important role in activating the consumer market and promoting and expanding employment in the future. 
As a matter of fact, as early as a few years ago, Liu Jianping, member of the CPPCC Provincial Committee and vice chairman of Foshan Municipal Committee of the democratic revolution, put forward the proposal of "time bank" for the problem of providing for the aged. The mode of its operation (Gong Chen and Guo-Gui Huang, 2017; Hai-Jian Li, Wen-Jie Li and Ran Li, 2020) [1] [2], similar to the "shared time bank" platform proposed by us, and from the establishment of the first "time bank" to 2018, there are more than 100 "time banks" in the United States, and more than 100 are in the process of brewing, which have been spread to all corners of the world, benefiting nearly 200 million people (Ozanne, 2010; Seyfang, 2004) [3] [4].

\section{Research Method}

The saying of tree hole originated from a fairy tale, which tells the story of the protagonist facing a secret that he can't share. At present, the biggest "tree hole" on Weibo comes from a user named "zoufan", whose indifference attracts many people to leave messages on Weibo.

In view of this, we use case study to explore the way of Wish Magic to do. As a service platform for sharing resources, adhering to the development concept of "sharing resources with science and technology", through the combination of artificial intelligence and big data, it provides online consultation and practical problem solving + offline activities and lectures.

\section{Research Results}

In 1995, Edgar Kahn, an advocate of time bank, was in Robert Wood Johnson Foundation founded the first real time bank in the United States. After decades of development, time bank has spread to more than 20 countries in Europe, North America and Asia, with 109 in the UK alone. Since 1999, time bank has been launched in Shanghai, Beijing, Chengdu, Nanjing, Guangzhou and Jinan in China.

At present, time bank takes time as currency, and uses corresponding time to exchange for the service time of the other party. It mainly relies on residential areas, and focuses on the elderly. Therefore, time bank still lacks online communication platform, and the range of audience is limited, which makes people have the problem of idle resources.

In the era of "Internet + ", the emergence of sharing economy has greatly solved the allocation of idle resources in the market. By collecting the actual idle resources and showing them to the departments in need, sharing economy has greatly facilitated people's daily life, enabled consumers to enjoy cost-effective goods or services, and solved the production problems caused by different aspects.
Besides, in terms of the user scale of sharing economy, we can learn from the data analysis of three countries with relatively mature development of sharing economy, including the United States, the United Kingdom and Canada. According to statistics, as of 2014, 120 million, 33 million and 14 million people in the United States, the United Kingdom and Canada have participated in the sharing economy.

In addition, according to the survey and calculation of the realization of labor economic rights and interests of enterprise workers in the Research Office of the China Federation of Trade Unions, labor dispatch workers account for $13.1 \%$ of the total number of enterprise workers, about 37 million people. From the perspective of industry distribution, the vast majority of industries use labor dispatch workers. In the 20 categories of national economic industries, 16 of them use labor dispatch workers, among which the number of labor dispatch workers, and more than $20 \%$ of the surveyed enterprises use labor dispatch workers in 11 categories.

In view of this, it can be seen that at present, labor dispatch is more and more widely used in the domestic field, and the dispatch scale is also growing. 93\% of large enterprises (more than 500 people) accept the labor dispatch service to varying degrees. With the gradual recognition of national policy on labor dispatch, more and more enterprises will choose labor dispatch in the future. The development of domestic labor dispatch will show the following trend Potential: the market scale will continue to expand and the degree of standardization will continue to improve.

To solve the problem of surplus energy, idle resources can really play their economic value, and then continuously improve the corresponding income, promote the sustainable development of social economy, so the time sharing bank will have a broader space for development.

With the social and economic progress and the rise of the Internet, the sharing economy has developed rapidly in the world, creating new opportunities. "Wishing tree hole and spitting tree hole combined with sharing time bank" project is a product derived from the concept of "sharing economy" (see Table 1). They use modern information technology to operate, in line with the development trend of the times. They play a more and more important role in the sharing economy and the internet.

Today, with more and more important role, and a series of policies issued by the government, such as "opinions on supporting the healthy development of new formats and new models, activating the consumer market and promoting the expansion of employment" and "Internet +", all show that the project of "combining wishing tree hole with spitting tree hole and sharing time bank" has a bright future. 
Table1. Package charge standard by service mode.

\begin{tabular}{|c|c|c|c|c|c|}
\hline $\begin{array}{l}\text { Service } \\
\text { Mode }\end{array}$ & Frequency & Week & Month & Quarter & Year \\
\hline $\begin{array}{l}\text { Artificial } \\
\text { Voice }\end{array}$ & $\begin{array}{c}25 \text { Yuan / } \\
\text { Hour }\end{array}$ & $\begin{array}{l}450 \text { Yuan / } \\
14 \text { Hours }\end{array}$ & $\begin{array}{c}1,600 \text { Yuan / } 60 \\
\text { Hours }\end{array}$ & $\begin{array}{c}7,000 \text { Yuan / } \\
180 \text { Hours }\end{array}$ & $\begin{array}{c}28,000 \text { Yuan / } \\
720 \text { Hours }\end{array}$ \\
\hline $\begin{array}{c}\text { Online } \\
\text { Psychology } \\
\text { Training and } \\
\text { Teaching } \\
\end{array}$ & - & - & $\begin{array}{l}500 \text { Yuan / } \\
\text { Month }\end{array}$ & $\begin{array}{l}\text { 1,400 Yuan / } \\
\text { Quarter }\end{array}$ & $\begin{array}{c}\text { 5,800 Yuan / } \\
\text { Year }\end{array}$ \\
\hline $\begin{array}{l}\text { Customized } \\
\text { Service }\end{array}$ & \multicolumn{5}{|c|}{ Another Discussion on the Price of Personalized Customized Service } \\
\hline $\begin{array}{l}\text { Famous } \\
\text { Offline } \\
\text { Teacher } \\
\text { Lecture }\end{array}$ & $\begin{array}{l}150 \text { Yuan / } \\
\text { Set }\end{array}$ & $\begin{array}{l}\text { Once Every } \\
\text { Two Weeks }\end{array}$ & $\begin{array}{l}360 \text { Yuan / } \\
\text { Month (2 } \\
\text { Times) }\end{array}$ & $\begin{array}{c}\text { 1,080 Yuan / } \\
\text { Quarter (6 } \\
\text { Times) }\end{array}$ & $\begin{array}{c}3,600 \text { Yuan / } \\
\text { Year }(24 \\
\text { Times })\end{array}$ \\
\hline $\begin{array}{l}\text { On Site one- } \\
\text { to-one } \\
\text { Consultation } \\
\text { Activities }\end{array}$ & $\begin{array}{l}200 \text { Yuan / } \\
\text { Hour }\end{array}$ & - & - & - & - \\
\hline $\begin{array}{l}\text { Professional } \\
\text { Psychology } \\
\text { Coaching } \\
\text { and Training }\end{array}$ & $\begin{array}{l}200 \text { Yuan / } \\
\text { Time }\end{array}$ & $\begin{array}{l}\text { 1,200 Yuan } \\
\text { / Week }\end{array}$ & $\begin{array}{l}\text { 5,300 Yuan / } \\
\text { Month }\end{array}$ & $\begin{array}{c}\text { 18,000 Yuan / } \\
\text { Quarter }\end{array}$ & $\begin{array}{c}60,000 \text { Yuan } / \\
\text { Year }\end{array}$ \\
\hline $\begin{array}{c}\text { Panel } \\
\text { Discussion }\end{array}$ & $\begin{array}{c}20 \text { Yuan / } \\
\text { Hour (1 Hour } \\
\text { / Time) }\end{array}$ & $\begin{array}{c}20 \text { Yuan / } \\
\text { Week (Once } \\
\text { a Week) }\end{array}$ & $\begin{array}{c}70 \text { Yuan / } 4 \\
\text { Hours (4 Times } \\
\text { a Month) }\end{array}$ & $\begin{array}{c}230 \text { Yuan / } 12 \\
\text { Hours (12 } \\
\text { Times in the } \\
\text { First Quarter) }\end{array}$ & $\begin{array}{c}950 \text { Yuan / } 48 \\
\text { Hours ( } 48 \\
\text { Times a Year) }\end{array}$ \\
\hline
\end{tabular}

\section{Conclusions and Suggestions}

Why should China vigorously support the development of sharing economy? Since the 2008 global financial crisis, the global market has shrunk, and China is facing problems such as overcapacity, aging and resource and environmental constraints. The downward pressure on the economy has increased, the rate of return on investment has decreased, and social resources have been idle and wasted, as well as the imbalance of industrial structure.

Sharing economy has brought new impetus to China's economic transformation and upgrading, and will become a new growth pole of China's economy. According to the data released by the state information center, the scale of China's sharing economy in 2015 was about 1.95 trillion yuan, and the number of people participating in sharing economic activities has exceeded 500 million. It is estimated that the average annual growth rate of sharing economy will be about $40 \%$ in the next five years, and the market size will account for more than $10 \%$ of GDP by 2020.

At the same time, sharing economy is a revolution at both sides of "supply side" and "demand side".

On the "supply side", a large number of idle funds, land, technology and time can be effectively supplied through the internet platform, which can solve the problem of resource shortage and a large number of idle waste coexisting in our country, and transform residents' private resources into social public supply. For example, Wish Magic can use the internet platform to realize the effective supply of a large number of idle funds, land, technology and time. The idle professional and technical talents are transformed into the effective supply of the society, which alleviates the problems of the insufficient effective supply of government public services such as education, medical care and pension.

On the "demand side", the sharing economy can effectively match the needs of consumers and meet the needs with the lowest cost. Consumers save a lot of "search cost", and can timely understand other consumers' demand for goods and services.

Based on the above analysis, it can be seen that China's macro environment is very beneficial to the development of innovative teams in the sharing economy, which will provide a good environment for the development of Wish Magic. 


\section{References}

1. Gong Chen, Guo-Gui Huang (2017) Local development, practice and innovation of time bank - also on the new ideas of actively coping with China's aging population. Beijing University Journal of Philosophy and Social Sciences, 54(6): 112-120.

2. Hai-Jian Li, Wen-Jie Li, Ran Li (2020) A study on the future pension model in China: The expansion path of time bank. Managing the world, 3: 76-89.

3. Ozanne, L. (2010) Learning to exchange time: Benefits and obstacles to time banking. International Journal of Community Currency Research, 14: 1-16.

4. Seyfang, G. (2004) Working outside the box: Community currencies, time banks and social inclusion. Journal of Social Policy, 33(1): 49-71. 